June 1990

\title{
The Real Mother-Issues in Adoption
}

Penelope J. Hooks, M.D.

Baylor College of Medicine, Houston Texas

Follow this and additional works at: https://jdc.jefferson.edu/jeffjpsychiatry

Part of the Psychiatry Commons

Let us know how access to this document benefits you

\section{Recommended Citation}

Hooks, M.D., Penelope J. (1990) "The Real Mother-Issues in Adoption," Jefferson Journal of Psychiatry. Vol. 8 : Iss. 2 , Article 8.

DOI: https://doi.org/10.29046/JJP.008.2.005

Available at: https://jdc.jefferson.edu/jeffjpsychiatry/vol8/iss2/8

This Article is brought to you for free and open access by the Jefferson Digital Commons. The Jefferson Digital Commons is a service of Thomas Jefferson University's Center for Teaching and Learning (CTL). The Commons is a showcase for Jefferson books and journals, peer-reviewed scholarly publications, unique historical collections from the University archives, and teaching tools. The Jefferson Digital Commons allows researchers and interested readers anywhere in the world to learn about and keep up to date with Jefferson scholarship. This article has been accepted for inclusion in Jefferson Journal of Psychiatry by an authorized administrator of the Jefferson Digital Commons. For more information, please contact: JeffersonDigitalCommons@jefferson.edu. 


\title{
The Real Mother-Issues in Adoption
}

\author{
Penelope J. Hooks, M.D.
}

\begin{abstract}
Our society has deemed adoption a desirable alternative method of creating a family. It satisifies the need of a child for parents, it gratifies the desire of adults who yearn to provide a home and love for a child, and it gracefully solves the dilemma for the one who cannot or will not raise the child. In addition to the usual developmental conflicts, families involved in adoption will encounter a variety of fears, fantasies, resentments, and misconceptions which may adversely affect identity formation in the child. Here I will attempt to explore some of the psychodynamic issues which will be of help to beginning therapists in their work with adoptive families.
\end{abstract}

Adoption legally establishes a parent-child relationship where no such relationship exists naturally. The process of adoption has its origins in antiquity, where the proliferation of the family heritage looked to the male lineage for restitution. The importance of the male heir stemmed from political, religious, or economical considerations. Laws throughout the ages have reflected this tendancy to value family heritage. Roman law, for example, was established in the interest of wealthy, childless citizens who wished to adopt an adult male heir as beneficiary (1). In more recent history we see a continuation of this ancient bias. In the 18th century the French Code Napoleon was established to promote the interests of adoptive parents; the welfare of the child was secondary. Not until a Massachusetts law was passed in 1851 was the welfare of the child considered to be primary in the legislature. It was as late as 1926 before English Common Law no longer regarded the child as property. Up until this time it was still legal to leave a child abandoned on a doorstep with a note and a piece of bread, as portrayed in the novels of Charles Dickens. Although the desire to continue a particular family line or to secure rights to inheritance may be among the personal motives for adoption, society has shifted its interests. The current concern is for the well-being of the child and the creation of a nurturing parent-child relationship. The field of psychiatry has an important place in this area.

In the U.S., $80 \%$ of all adoptions occur before one year of age (1). The remaining $20 \%$ are primarily adoptions by stepfamilies or adoptions of older

Address correspondence to Dr. Hooks, 3624 Rice Boulevard, Houston, TX 77005. 
children. This article will deal specifically with adoptions occurring in infancy. Here the expectation is that the child has never belonged anywhere but in his adoptive family. Furthermore it is assumed that the child has no other history, background, or significant relationships.

The process of adoption is fairly uniform in most states and requires several prerequisites. First the child must be legally separated from his parents. Second the transfer of custody to a licensed adoption agency must be granted by the parents, including the father if he is known. Finally, after placement with the adoptive family for a probationary period of about six months, a family court can transfer parental rights and responsibilities to the adoptive parents.

Prior to placement, the adoption agency will assess the emotional maturity and appropriateness of the prospective couple. This is called the Home Study and consists of several interviews with a social worker. When the child is placed in the home for the probationary period the potential adoptive parents are provided with biological, ethnic, and medical data on the child, as available. During the probation period the parents must provide monthly reports to the agency which document such things as visits to the pediatrician, photographs of the developing child, and any requests to leave the state for vacations or other reasons. This sense of violation of basic civil rights will be mentioned again later when discussing dynamic issues. At the end of the probation period a court hearing is scheduled where the parents may present their formal request for adoption. When this is granted, when all rights and responsibilities have been reassigned, the court allows for a new original birth certificate to be issued. It certifies that the child was born to the adoptive parents, listing them by name. The city of birth however, is the actual one rather than the one where the new family lives, serving as a reminder to everyone that some discrepancies still exist in the story (2). There are presently about 2 million children, approximately $2 \%$ of the U.S. population under 18 years of age, who are extra-familial adoptees (1). The annual incidence of adoption is about 150,000 cases per year (1). Sixty percent go through state agencies, the remainder are independent or private adoptions. In reports of psychiatric practices, adoptees comprise anywhere from $2.6 \%$ to $25 \%$ of total caseloads (3). Schechter, 1960, reported a high incidence of adoptees in psychiatric practice. He reported symptoms of increased aggression in boys and sexual acting out in girls (3). More girls than boys are adopted to a significant degree, probably still owing to the idea that sons carry on the bloodline. However more adopted boys than girls are seen in psychiatric clinics (3), but, then, more boys in general are seen in psychiatric practices. Intelligence Quotient estimates have been found to be lower in adoptees than in nonadoptees of the same socioeconomic class (5). The psychiatric manifestations of adoption are clearly immense, at times causing authorities to question the ultimate benefit of adoption. What needs to be taken into consideration here is that even if IQ's are statistically lower than in the general population of non-adoptees, the IQ's are higher than those children of single mothers who chose to raise their own illegitimate children. It will be of interest to psychiatrists 
that $50 \%$ of children adopted as infants were born out of wedlock (1). Seventy percent of white mothers of illegitimate children chose to place their babies for adoption (1). Ninety percent of birthmothers who place their babies for adoption sign that they would like to be found when the child reaches maturity (3). Interestingly, it is more often girls rather than boys who do eventually seek to find the birthmother (3).

The issue of adoption is one of major importance to a family, no matter how casually or indifferently it may be mentioned in the history. To elicit this history, careful attention to the use of emotionally neutral terms will be well worth the conscious effort. Let us now examine the connotations of some of the most frequently encountered terms.

"Adoption" is a process by which a family is created. Although it is not the most common way, it is not an inferior way. One should be sensitive to the idea that many adoptive mothers devalue themselves in this way. An adoptive mother should know that she, the psychological mother, is the full mother as far as the child is concerned. She will face the same joys and sorrows as a natural mother.

A child is not "put up" for adoption. This idea is a remnant from 18th century England where the practice was to put children up on a stage for auction. The term "put up" connotes "given up," whereby feelings of loss and abandonment prevail. A more gentle, less painful, but still technically accurate term is that he was "placed" for adoption.

The child may often fantasize about his "real" mother. It may be helpful to introduce the terms "natural," "biological," or "birthmother." This provides a way for him to distinguish which person he is talking about while still fully accepting his adoptive mother.

To say that Johnnie "is" adopted implies a permanent state of being, a lifelong identity which he can never live down. Johnnie "was" adopted implies a one-time event in his life which occurred in the past and has little present significance.

It is not "before we 'got' Susie," but rather "before Susie 'was born." " All children were born. All children have birthdays. A birthday should be celebrated. "Gotcha-Day" is optional.

An important issue in working with adoptive families is one of when and how to tell the child of his adoption. The literature on child development would suggest that the latency period, that is early elementary school age, is the best "time to tell" (1). This child has a better grasp of reality than the pre-Oedipal child, who has too many other identity conflicts. Early "telling" evokes fantasies of cruelty, rejection, and longing for the original parent (1). In contrast, Helene Deutsch felt that a "good mother" will find the right time (4). The mother knows her particular child and will sense the empathic moment when he both wants to know and can assimilate the information.

"Telling" is a gradual process and not a single event. It should emphasize what each has gained, not lost. The child has found parents and a family. He has not lost parents he has never had. His mother will want to acknowledge the 
differences he feels and offer support for his concerns. Denial and repression of the differences lead to breakdown of communication between parent and child and feelings of guilt may grow on both sides (5). Parents should not mislead the child by saying that they selected him specifically or that he is more special than others. While it sounds comforting to be considered so special, the child may fear disappointing the parent if he fails to live up to this ideal.

There are many recurring fantasies on everyone's part in the issue of adoption. The child, the adoptive parents, and the birthparents all generate their own ideas. The child in particular is prone to many fantasies about his identity and his heritage. Listed here are some commonly explored fantasies of adopted children (1).

1. My biological mother must have resented me and considered me bad if she gave me up.

2. If my biological mother could give me up, there is a chance my adoptive mother could give me up also. This fear can be easily evoked by such a simple thing as giving away a family pet.

3. I am angry at my adoptive mother for taking me away from my real mother.

4. I could actually marry my adoptive mother since the usual incest taboos do not apply.

5. I believe that I am the child of someone rich and famous like a king and queen, and have been stolen by these ordinary parents. The Family Romance Fantasy tends to be more intense because he in fact does have two sets of parents.

6. I challenge your authority and refuse to obey you since you are not my real mother.

7. My mother is infertile and therefore pure. In the case of a girl who identifies with her mother's sexuality, she may have conflicts about her own sexuality.

In a survey of adolescents who have been adopted, this is what three of them had to say about how it feels to think about being adopted.

It really makes me upset when people say to me, “Oh, you're adopted just like him. You two should stick together." He's a kid who talks back to teachers and writes on the walls. I don't even want to be near him.

I don't think I'll ever search out my birthmother ... If she searched for me, I'd be willing to go out to dinner with her, and I'd probably like to ask her a few questions. I wouldn't want to stay with her, or anything like that. I have one question I'd like to ask her. How does she feel on my birthday? (Carla, age 12) (6)

When I was a kid, my friends would say, "Let's go over to Jack's house to play. He's adopted and his parents have to be nice to him." (Jack, age 12) (6) 
I've often thought if I found out where she (my birthmother) was, I think I'd pretend I was an Avon lady or something and go up to her house and just see how everything was. I'd look things over and see what she was like. Then I could decide whether or not to tell her why I was there. (Pattie, age 15) (6)

One anxious adult adoptee who had recently successfully searched for her natural mother voiced these feelings to her Therapist:

I never expected to get results. Finally I'll get to know who I am, where I came from, who I look like. I grew up as an only child and I find I have one full brother and two half sisters. Exciting, but not what I expected. I believed the fairy tale that she had done well for herself after she had me. She's living in poverty, 8th grade education, married 5 or 6 times, opposite of what I had expected. The bond is with the parents I grew up with, I can't foresee a bond with my biological mother. She wrote me a letter saying she'd like to thank "this woman" for "taking care of you." Can she now suddenly reclaim me as though my parents were just babysitting me? I don't think I can just go running to her. . . I used to get angry when people would say I looked like my mother. There isn't any way in heaven I could look like her, I'm adopted . . . How do I fit into things? I am two people (7).

While the adoptee considers "Who am I?," the adoptive mother struggles with "Who are you?" (1) Turning now to the emotional background of the adoptive mother, we find that she too has difficulties. Adoption is usually preceeded by a period of infertility, an inability to have one's own child. There are sexual conflicts and often the couple has narrowly survived the threat of divorce (2). Each may have considered the possibility that if he were married to another partner he would be able to have a baby. The financial strain must also not be forgotten. The medical expenses of infertility work-ups, surgery, medications, and diagnostic procedures may run into the $\$ 50,000$ range. Adoption itself often runs in the $\$ 20,000$ range. By this time, the wish for children may be conflictual (2).

There is a long period of uncertainty and waiting, but without a period of pregnancy to anticipate the changes. Since the baby is not adoptable until after its birth and after the mother has made her final decision to terminate parental rights, notification comes on the spur of the moment, often the news comes as a phone call from the Agency, "We have a baby for you. Can you be here in about two hours" (2)?

The Narcissistic blow of infertility is often most severe when it is the mother who is completely barren. Things are somewhat better if it is her husband who is sterile, or if she has had one natural child first. If infertility is the result of complications of an abortion or venereal disease, guilt adds to the situation (5).

The child constantly reminds the parents of their inability to conceive and 
serves as a constant source of hostility. If the mother's narcissism remains uncompromising, and demands on the child are not reduced, the adoptive mother's disappointment reactions are blamed on reality— it's not my child' (1).

Reactions to infertility may vary. Often she may be very matter of fact, show little affect, and apply for adoption as an automatic response (5). This does not allow for a period of grieving. Ideally, she would talk about the problem, cry, and gradually think of adoption as the depression subsides. She needs to grieve her loss of reproductive function, and the loss of natural children that were expected but never came. In the case of inadequate grieving, there may be denial and repression of adoption (5). She may fail to remember the child's birthdate or reject or refuse to acknowledge any differences between herself and other mothers. She then is not in a position to support her child when he has questions or concerns about adoption.

Parental conflict over adoption is usually played out with the first child (5). Communication is usually better with the second child because by then adoption is more accepted by the family. There is always some degree of loss regarding the child.

There is not a connection between placement or legal adoption and emotional committment to the child $(1,3,5)$. A person suffering a loss cannot accept or love a substitute object until she has grieved and accepted the loss of the object. She attempts to circumvent natural grief by impulsively seeking solace in a new relationship. Cathexis remains with the fantasized natural children and is not available for the adopted one. If the parents have grieved, they can have empathy with the child, understand problems of the adoptive status, and help him come to grips with the loss of his background $(2,3,5)$.

Since there is a probation period between placement and adoption, it is a risk to make a full committment to a child who could be snatched away at any moment. The mother perceives the Agency a threatening intruder. In her mind the Agency esists to pass judgement on her adequacy as a mother, and it infantilizes her by serving as the authority from whom she must seek permission before making decisions which concern her child (2). If the child needs surgery, she cannot give permission, she cannot take the child out of state, and since it is not yet her child, the birthmother as well as the Agency has access to the photographs and letters she sends in. It is not surprising then that she does not avail herself of the counseling services offered. She resents being investigated as a parent, when no such requirements exist for becoming a biological parent if one desires. Anxiety over losing the child between placement and adoption has an impact on the mother/child relationship. She maintains on a deep level that she is raising someone else's child and expects the child to identify with shadowy images of the biological parents rather than themselves (1). If she can provide affection, stimulation, and unbroken continuity for the child, identification will fortunately take care of itself.

The way in which the adoptive mother is affected by the fact of adoption will 
undoubtedly influence the way in which she relates to her child. The adoptive mother's fantasies run along these lines $(1,2)$ :

1. I still have a romantic longing for the child of my father. Oedipal desires often attenuate when a woman finds herself capable of giving birth herself. In the case of the adoptive mother, oedipal frustration rages on.

2. My own mother has defeated me. The adoptive mother retains a sense of inferiority in relation to her own mother, constituting Oedipal defeat.

3. The Wild Seed is fated to repeat the sin. The Wild Seed Fantasy derives from the fantasy that the birthmother must have been promiscuous and indecent, and will pass those qualities on in the genes to her offspring. Parents blame irritating behavior on "Bad Heredity," the child feels unwanted, leading to delinquent behavior. Parents may act out their unacceptable fantasies through the child.

4. My child's father must have been quite a lover. Fantasies toward the adopted child's father may have implications on the marriage.

5. There must be something bad about this child that you know that I do not. There are fantasies of why the child was abandoned. Another variation of this fantasy is that if the birthmother knew how beautiful the child was, she would want it back.

6. This child should love me more than normal children love their mothers since I have rescued him. There may be resentment toward the ungrateful child who was rescued.

7. This is my Miracle Child and he will bring all the fame and happiness to our family which has been missing for so long. There may be fantasies of miraculous fulfillment, the child genius. How disappointing if the child is just ordinary, or worse if he is handicapped or deficient.

8. My child will stop loving me if I tell him he is adopted. In order to avoid the pain of the fantasied rejection, she may withdraw her love at the time of telling him of the fact of his adoption. There is then a disruption of her libidinal investment in the child.

Included here is a compilation of one adoptive mother's experience, which may be typical of the expressions of grief heard in therapy with patients:

There were bad times, you know. Did you know your-my-our daughter almost died from an asthma attack when she was eight? I said to myself, "Where the Hell are you now, Real Mother?" . . Y You want to know what Real is? Real is what hears "I hate you" and still says No . . . Real is emergency rooms, PTA's . . . lies, defiance, and slammed doors . . . But mostly you have been the object of my envy ... You had that wonderful experience that I would have given anything to have ... the movement inside me of a child ... No one can give it to me. . . (8). 
Finally, the birthmother also does not readily forget the trauma of her lonely and conflicted pregnancy and delivery. Her fantasies include:

1. Does my child hate me?

2. Would he in fact have been better off with me?

3. Will I be punished by never having further children?

4. What will his new mother tell him about me?

5 . Was what I did right or wrong?

6 . If my child were to die, would they notify me?

7. I wonder if my child is here in this crowd and I have missed it.

Here is an account of what one birthmother, who was in Psychotherapy, said as she poignantly explained how her decision to elect for adoption was made.

I told my mother first (about the pregnancy) and she asked me who the father was. She said she was going to call his parents. Then she decided maybe it was best if few people knew about it. She decided it was better for me to go away for a few months to have my baby, then give her up for adoption. It never occurred to me that I could keep my baby. Life at home was pretty bad. I had grown up in turmoil all my life. My father was an alcoholic. My parents fought all the time. Life was a living hell. I had no love for myself. I could never have brought you (my baby) into this (2).

Another birthmother wrote a letter to the imagined adoptive mother of her child, dramatizing what she would like to say to her if they were ever to meet.

Joanie-I like the name you chose for her. I named her Lisa even though I knew you'd change it ... I was told that you were a better person than I was to be her mother. Were you? I wanted her to have a real family. Have you been a real family? I hope so. . . . Once my name was on the dotted line, no one ever thought twice about me or my feelings. ... For years I felt like nothing because of the decision I made ... there was no one to answer my need to know. ... Is she happy ... does she like sports ... does she hate me ... does it bother you that I want to know about your daughter?. . . The laws are such that they don't want me to know anything . . . they even went so far as to say I'd forget her. I never did. They said she needed two parents. . . . Were the experts wrong?. . . I got to carry her and feel her grow ... Yet once my purpose was over, I wasn't needed anymore... you then became Real (8).

The birthmother's sense of guilt, pain, sorrow, and neverending loss is an issue which the adoptive mother has difficulty acknowledging. The hostility and envy that each feels for the other is at times thinly disguised under the veil of altruism and benevolence. 
Even though the outcome of adoption may be more desirable than not, losses are sustained by all parties. These losses must certainly affect the identity of the adoptee. The process of adoption takes a lifetime to complete. Patients who seek psychotherapy concerning adoption will profit from a therapist who is sensitive to the deep personal significance it has for the members of these families.

\section{REFERENCES}

1. Schechter D: Psychoanalytic Theory as it Pertains to Adoption. Fall Meeting of the American Psychoanalytic Association, New York 1966

2. Case Material, Hooks J, Resident in Psychiatry, Baylor College of Medicine, Houston, 1989

3. Schechter D, Carlson V, Simmons Q III, Work H: Emotional Problems in the Adoptee. Archives of General Psychiatry, 1964

4. Deutsch H: The Psychology of Women, Vol 2, New York, Grune and Stratton, 1945

5. Kent G, M.S., Richie, JL: Adoption as an Issue in Casework with Adoptive Parents. Annual Meeting of American Psychiatric Services for Children, Washington, D.C., 1972

6. Krementz J: How it Feels to be Adopted, New York, 1983

7. Case Material, Lomax J, Residency Director, Department of Psychiatry, Baylor College of Medicine, Houston, 1986

8. The Real Mother, Erma Bombeck's Column, Women's Day, October 4, 1982 